Review

\title{
The Emerging Role of LHb CaMKII in the Comorbidity of Depressive and Alcohol Use Disorders
}

\author{
Chaya Shor, Wanhong Zuo, Jean D. Eloy and Jiang-Hong Ye * \\ Department of Anesthesiology, Rutgers, New Jersey Medical School, 185 South Orange Avenue, \\ Newark, NJ 07103, USA; tzivia54@gmail.com (C.S.); zuowa@njms.rutgers.edu (W.Z.); \\ eloyje@njms.rutgers.edu (J.D.E.) \\ * Correspondence: ye@njms.rutgers.edu
}

Received: 27 September 2020; Accepted: 26 October 2020; Published: 30 October 2020 updates

\begin{abstract}
Depressive disorders and alcohol use disorders are widespread among the general population and are significant public health and economic burdens. Alcohol use disorders often co-occur with other psychiatric conditions and this dual diagnosis is called comorbidity. Depressive disorders invariably contribute to the development and worsening of alcohol use disorders, and vice versa. The mechanisms underlying these disorders and their comorbidities remain unclear. Recently, interest in the lateral habenula, a small epithalamic brain structure, has increased because it becomes hyperactive in depression and alcohol use disorders, and can inhibit dopamine and serotonin neurons in the midbrain reward center, the hypofunction of which is believed to be a critical contributor to the etiology of depressive disorders and alcohol use disorders as well as their comorbidities. Additionally, calcium/calmodulin-dependent protein kinase II (CaMKII) in the lateral habenula has emerged as a critical player in the etiology of these comorbidities. This review analyzes the interplay of CaMKII signaling in the lateral habenula associated with depressive disorders and alcohol use disorders, in addition to the often-comorbid nature of these disorders. Although most of the CaMKII signaling pathway's core components have been discovered, much remains to be learned about the biochemical events that propagate and link between depression and alcohol abuse. As the field rapidly advances, it is expected that further understanding of the pathology involved will allow for targeted treatments.
\end{abstract}

Keywords: lateral habenula; CaMKII; addiction; drugs of abuse; alcohol; depression; comorbidity

\section{Introduction}

Alcohol use disorders (AUDs) is the medical diagnosis given to individuals who are suffering from severe problem drinking. AUDs are chronic relapsing brain disorders characterized by an impaired ability to stop or control alcohol use despite adverse social, occupational, or health consequences. AUDs are a severe problem in the United States. According to the National Institute of Health Alcohol Facts and Statistics, in 2018, in the United States, AUDs affect an estimated 15 million people, 5.8 percent or 14.4 million adults (ages 18 and older). This includes 9.2 million men and 5.3 million women. AUDs also affect an estimated 401,000 adolescents between the ages of 12 and 17 (National Institute on Alcohol Abuse and Alcoholism (NIAAA): Understanding the impact of alcohol on human health and well-being).

In 2018, 26.45 percent and 6.6 percent of adults engaged in binge drinking or heavy drinking, respectively. An estimated 88,000 people (62,000 men and 26,000 women) die from alcohol-related causes each year, making alcohol the third leading preventable cause of death in the United States 
(Centers for Disease Control and Prevention. Alcohol and Public Health: Alcohol-Related Disease Impact). In 2014, 9967 deaths (31 percent of overall driving fatalities) were due to alcohol-impaired driving (Traffic Safety Facts CrashStats. Report No. DOT HS 812 219, Washington, DC: National Highway Traffic Safety Administration, 2015). AUDs are a severe economic burden on society. In 2010, alcohol misuse cost the United States $\$ 249$ billion [1]. Three-quarters of the total cost of alcohol misuse is related to binge drinking [1]. AUDs seriously affect family life. According to a 2012 study, more than 10 percent of children in the U.S. live with a parent with alcohol struggles.

AUDs are also a severe problem worldwide. According to the World Health Organization (WHO), in 2012, the harmful use of alcohol caused 3.3 million deaths globally, or 5.9 percent of all global deaths (7.6 percent for men and 4.0 percent for women) (WHO Global status report on alcohol and health, 2018). In 2014, the WHO reported that alcohol contributed to more than 200 diseases and injury-related health conditions, most notably, Diagnostic and Statistical Manual of Mental Disorders-4 (DSM-IV) alcohol dependence, liver cirrhosis, cancers, and injuries. In 2012, 5.1 percent of the burden of disease and injury worldwide (139 million disability-adjusted life years) was attributable to alcohol consumption (WHO Global status report on alcohol and health, 2018). Globally, alcohol misuse was the fifth leading risk factor for premature death and disability in 2010. It was the primary risk factor among people between the ages of 15 and 49 (WHO Global status report on alcohol and health, 2018). In the age group of 20-39 years, 25 percent of the total deaths were attributable to alcohol consumption (WHO Global status report on alcohol and health, 2018).

In the same vein, depressive disorders (DDs), including major depressive disorders, are among the most prevalent neuropsychiatric disorders that can interfere with patients' functioning [2,3]. DDs are mood disorders characterized by sadness severe enough or persistent enough to interfere with function and often decreased interest or pleasure in activities. Individuals who suffer from DDs may have trouble doing normal day-to-day activities, think their lives are meaningless, and even engage in suicide ideations or behaviors. The exact cause of DDs is unknown, but it may involve a combination of heredity, changes in neurotransmitter levels, altered neuroendocrine function, and psychosocial factors.

AUDs often occur with other psychiatric conditions and this dual diagnosis is called comorbidity. This pattern of comorbidity adversely affects the prognosis, course, and treatment of both DDs and AUDs. High severity in one of these disorders is associated with high severity in another condition. Alcohol dependence prolongs the course of depression and increases the risk of suicidal symptoms and behaviors. DDs invariably contribute to the development and worsening of AUDs [4]. Patients with depression and AUDs are at increased risk of relapse to heavy drinking. However, the mechanisms underlying this association are not fully understood. This gap in our knowledge prevents us to find out a better treatment strategy for these comorbidities. Professionals working with patients suffering from these comorbidities face unique and challenging dilemmas about providing the best treatment to address both conditions. Despite the growing interest in this issue, relatively few clinical studies have tested treatments for this patient population [5]. This highlights the need to understand the etiology of the disorders and develop an effective treatment regimen.

Although many factors can contribute to the comorbidity of AUDs and DDs [6], the molecular interplay will be discussed in depth. Recently, the lateral habenula $(\mathrm{LHb})$ has emerged as a crucial brain region in the pathophysiology of DDs and AUDs. Fortunately, a detailed outline of the calcium/calmodulin-dependent protein kinase II (CaMKII) signaling pathway has emerged. The target of its signaling cascade in the LHb has proven beneficial for treating AUDs, especially for those with comorbid DDs [7].

\section{The Role of the Lateral Habenula in Depressive Disorders and Alcohol Use Disorders}

Before diving into CaMKII's prominent role in AUDs and DDs, it is essential to review the role of the habenula, a small structure in the brain located posterior to the thalamus and adjacent to the third ventricle [8-10]. The habenula is divided into two distinct regions: the medial habenula and the $\mathrm{LHb}$. The $\mathrm{LHb}$ has been neglected in the scientific literature because of its small size [11]. However, 
interest and research in the $\mathrm{LHb}$ have flourished in recent years due to the revelation that it becomes pathologically hyperactive in major depressive disorders [12-19]. The LHb receives relay information from the limbic forebrain and basal ganglia structures to basically all midbrain monoaminergic centers, including the serotonergic raphe and dopaminergic midbrain nuclei [8,20-22], controlling mood and emotions and playing a critical part in the brain's response to reward (Figure 1). Thus, the LHb is thought to have a role in the progression of depression and drug abuse $[7,13,23,24]$.

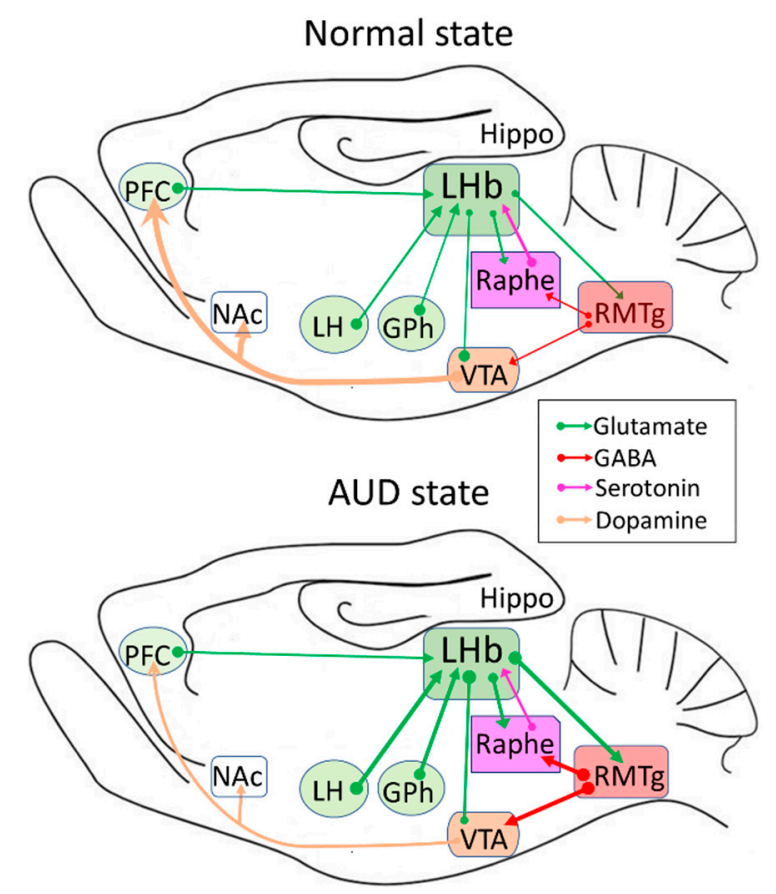

Figure 1. The brain network of the lateral habenula ( $\mathrm{LHb})$ in alcohol use disorders (AUDs) and its comorbidities. The LHb gets major inputs from the habenula-projecting globus pallidus (GPh), the prefrontal cortex (PFC), and the lateral hypothalamus (LH) and sends projections to dopamine neurons in the ventral tegmental area (VTA)/substantia nigra compacta (SNc) and serotonin neurons in the raphe directly or indirectly through the rostromedial tegmental nucleus (RMTg). The LHb also receives projections from the raphe. LHb's spike output and glutamatergic transmission are increased in alcohol withdrawal rats and in animal models of depression, suggesting that the LHb plays a key role in AUDs and depressive disorders (DDs) and their comorbidities.

The ability to seek and predict reward and pleasure and avoid confrontations is crucial for an animal's survival and well-being. The measure of the discrepancy between reward prediction and reward outcome is referred to as reward prediction error (RPE). It serves as a powerful incentive that guides approach or avoidance (go or no-go) behavior [23,25]. Positive RPE is when the actual reward exceeds the expected one and facilitates behaviors associated with reward (approach or go). Conversely, suppressed actions related to reward (avoidance or no-go) occur when the actual reward is smaller than expected, known as negative RPE [26].

Information about the reward state is transmitted via the outer region of the fasciculus retroflexus axon bundle that originates in the $\mathrm{LHb}$ to midbrain structures, particularly the rostromedial tegmental nucleus (RMTg). The RMTg is a small nucleus that consists of gamma-aminobutyric acid (GABA) cells [27], also known as the GABAergic tail of the ventral tegmental area [28]. The fasciculus retroflexus governs the release of glutamate onto GABAergic cells in the RMTg. The resulting GABA release from RMTg neurons inhibits dopamine cells in the ventral tegmental area (VTA)/substantia nigra compacta. This process allows the $\mathrm{LHb}$ to control dopamine levels in their target areas, such as the medial frontal cortex and nucleus accumbens (Figure 1). These structures have essential roles in a broad range of motivated behaviors and neuropsychiatric disorders [10,20,29-38]. Thus, positive RPE has been 
associated with the inhibition of $\mathrm{LHb}$ neurons and, therefore, increases in the firing of dopamine neurons. Since dopamine produces feelings of reward, drugs that induce increased dopamine levels have abuse potential [39-43]. In addition, correlating with a reward prediction error (the difference between expected and actual rewards), VTA dopamine cells can also signal aversion, saliency, uncertainty, and novelty [44]. In contrast, negative RPE is associated with LHb neurons' activation and decreases in dopamine neuron firing [45].

Additionally, the LHb projects to the midbrain serotoninergic system. This system plays a significant role in the motivation process [46], and its dysregulation contributes to drug addiction [47] and the etiology of mood disorders [48]. Like the projections to the midbrain dopamine neurons, $\mathrm{LHb}$ neurons project to the raphe serotonergic neurons either directly or indirectly through the RMTg $[20,27,49,50]$. LHb neurons projecting to the raphe are mostly in the medial part of the $\mathrm{LHb}$, and the medial raphe (MRN) receives more $\mathrm{LHb}$ projections than the dorsal raphe (DRN), as shown by tracing studies $[49,50]$. Studies using the rabies-based viral strategy and Cre driver mouse lines show that $\mathrm{LHb}$ neurons project to DRN/MRN serotonergic neurons and DRN GABA neurons [51,52]. Remarkably, the raphe also sends axons to the LHb. Studies using phalloidin anterograde labeling tracing techniques show that serotonergic fibers from the MRN and DRN are throughout the whole $\mathrm{LHb}[53,54]$. Studies using transgenic mice expressing Cre recombinase in serotonin-positive raphe neurons show that DRN serotonin cells project to the lateral portion of the $\mathrm{LHb}[55,56]$, consistent with the evidence that serotonin and its transporter are in the presynaptic side in the $\mathrm{LHb}$ [57-60]. For an overview on how the LHb integrates serotonergic signals, please read the recent review by Tchenio and colleagues [61].

Neurons in the LHb are almost uniformly glutamatergic [62,63]. The LHb inhibits the brain's reward centers, including the dopaminergic VTA [21,38,64] and the serotonergic DRN [20], either via the direct projection to local interneurons within the VTA and DRN $[7,27,36,38,65-67]$ or indirectly via the GABAergic relay in the RMTg $[27,28,58,68-70]$ (Figure 1). The tight connection between the LHb and monoaminergic neurotransmitter systems suggests a crucial role of the $\mathrm{LHb}$ in neuropsychiatric diseases including DDs [18,19,34,37] and AUDs [71,72]. Accumulating evidence in rodents and humans shows that the $\mathrm{LHb}$ exhibits hyperactivity during depressive states $[7,13,19,73-76]$ and alcohol withdrawal $[7,71,72,77]$. Conversely, a reduction of $\mathrm{LHb}$ hyperactivity by pharmacological or chemogenetic approaches, and deep brain stimulation or lesioning the $\mathrm{LHb}$ ameliorates depressive symptoms, including those in rats withdrawn from chronic alcohol $[7,12,13,67,78-80]$. Furthermore, $\mathrm{LHb}$ hyperactivity is involved in increased presynaptic glutamate release and upregulation of $\beta$ CaMKII, which enhances the function of postsynaptic $\alpha$-amino-3-hydroxy-5-methyl-4-isoxazolepropionic acid receptors (AMPARs) $[13,75]$. The role of CaMKII will be discussed in more detail in the later parts of this review.

Since it is a critical crossroad that influences brain responses to and encoding of aversive stimuli, such as stress, pain, anxiety, or pleasurable stimuli such as reward [23], the LHb has been correlated with major depressive disorders $[13,18,26,75]$. When rats and mice were treated with negative stimuli, $\mathrm{LHb}$ neurons were activated immediately $[72,81,82]$. Similarly, in vivo electrophysiological recording in monkeys showed that unexpected punitive signals such as an air puff in the eye, in addition to the omission of an expected reward, strongly excited LHb neurons [38]. Conversely, inhibiting LHb neurons suppresses depressive-like behaviors, as exhibited in animal models [7,17,71]. In addition to directly facilitating neuron activity, stress can alter the plasticity of $\mathrm{LHb}$ neurons, possibly contributing to long-term changes in the $\mathrm{LHb}$ under chronic stress, which can lead to depressive-like behaviors $[26,83]$. Though studies have shown enhanced synaptic activity and spike output of LHb neurons in animal models of depression, the precise molecular mechanisms by which depression leads to these changes are not yet understood $[13,19,75]$. Glutamate is the predominant excitatory neurotransmitter in the $\mathrm{LHb}$. Potentiation of glutamate transmission causes $\mathrm{LHb}$ hyperactivity, as occurs in AUDs and DDs $[7,13,26,71,77,84]$ (Figures 1 and 2). 

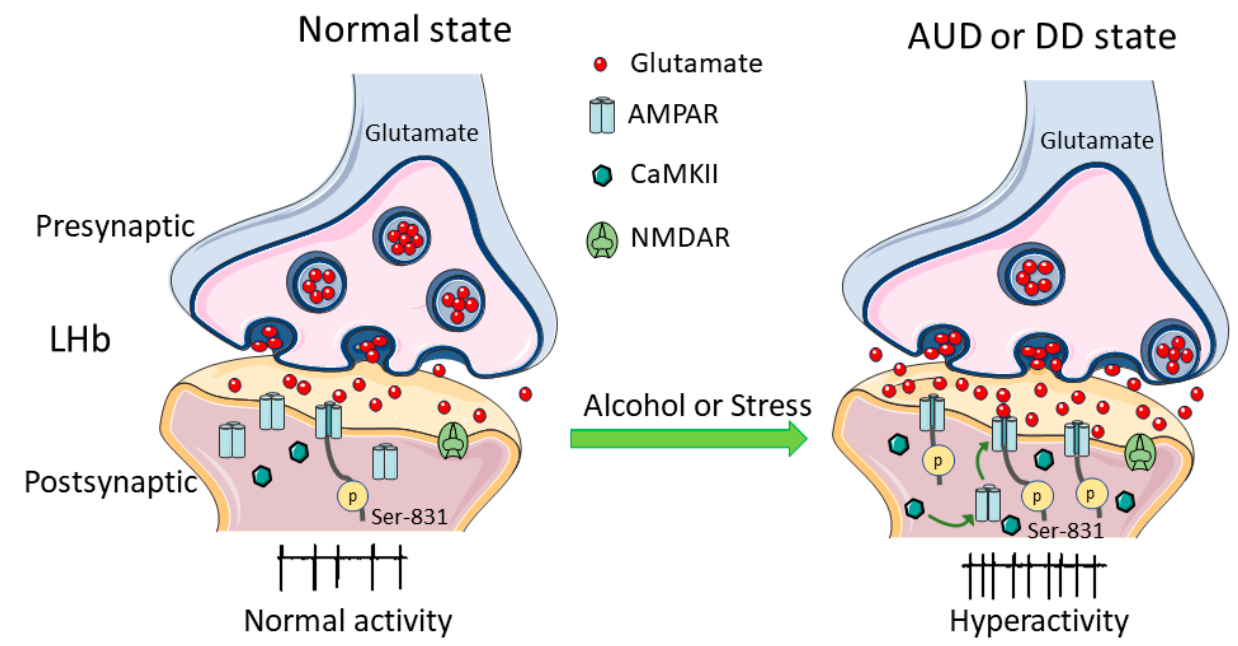

Figure 2. Changes of calcium/calmodulin-dependent protein kinase II (CaMKII) signaling in the $\mathrm{LHb}$ glutamatergic neurons in alcohol use disorders (AUDs) and depressive disorders (DDs). Withdrawal from chronic alcohol administration and stress enhance glutamatergic transmission to and the spike output of $\mathrm{LHb}$ neurons. This is due in part through phosphorylating serine 831 (Ser831) on the glutamate A1 (GluA1) subunit and activating the CaMKII.

Through a series of experiments and human genome-wide studies, the $\mathrm{LHb}$ is linked to addiction to drugs, such as cocaine, morphine, and alcohol [23]. Drugs of abuse cause addiction because they can increase the activity of VTA dopamine neurons and dopamine levels in the target areas, including the prefrontal cortex, nucleus accumbens (NAc), and striatum [40,85-87]. Akin to withdrawal from cocaine [88], withdrawal from chronic alcohol increases the firing of and the glutamate transmission to $\mathrm{LHb}$ neurons (Figures 1 and 2).

It is well accepted that the dopamine system, including the VTA, is involved in alcohol-seeking behavior and relapse $[87,89,90]$. Like other drugs of abuse, alcohol's reinforcing properties involve enhanced dopamine neuron activity. A large body of evidence suggests that transition from recreational to compulsive drinking, characteristic of AUDs, involves neuroadaptations in the mesolimbic reward system [90,91]. Although alcohol acutely activates mesolimbic dopamine neurotransmission, withdrawal from chronic alcohol leads to substantial decrements in VTA dopamine neuron activity [92-94] and extracellular dopamine levels in the NAc [95,96]. It is believed that this dopamine hypofunction leads to a negative emotional state that drives drug-seeking behavior to restore dopamine to normal, drug-naive levels [96-98]. However, the mechanisms causing this dopamine hypofunction remain unclear. Recent evidence from serious electrophysiological, immunohistochemical, molecular, and behavioral experiments points to a significant role played by the LHb. LHb neurons' hyperactivity during alcohol withdrawal may inhibit VTA dopamine neurons and lead to dopamine hypofunction, causing depressive symptoms such as anhedonia and anxiety $[7,58,69,71,77,97,98]$. These results provide strong support for a key role of the $\mathrm{LHb}$ in the connection between DDs, AUDs, and their comorbidities (Figures 1 and 2). However, our understanding of the mechanisms by which chronic alcohol administration and withdrawal as well as depression increase $\mathrm{LHb}$ spike output and glutamatergic transmission is incomplete.

\section{CaMKII Structure and Regulation}

Calcium ion $\left(\mathrm{Ca}^{2+}\right)$ is a ubiquitous second messenger in cellular signaling $[99,100]$. The chief intracellular receptor and modulator of $\mathrm{Ca}^{2+}$ is calmodulin (CaM), a highly conserved $\mathrm{Ca}^{2+}$ sensor, and its primary targets are protein kinases [101]. Saturation of $\mathrm{CaM}$ with $\mathrm{Ca}^{2+}$ induces a conformational change that allows the protein to interact with and activate a wide variety of downstream target enzymes [102]. One of the primary downstream targets of CaM is a family of enzymes known as calmodulin-dependent kinases (CaM-kinases), which are vital for proper cellular function. Members of 
the CaM-kinase family are classified as serine/threonine kinases. They all have either a serine or threonine on their substrate P-sites, the targeted locale for phosphorylation. CaMKII, in particular, is among the most well-studied members of the CaM-kinase family [102]. CaMKII is composed of 12 subunits that are arranged into two rings, each containing six subunits, allowing for regulating and modifying the function and localization of the kinase [103]. Four isoforms of CaMKII $(\alpha$, $\beta, \gamma$, and $\delta$ ) exist in mammals, each one expressed from a separate gene [102], and the $\alpha$ and $\beta$ isoforms are the most prevalent in the brain. The abundance of CaMKII in the nervous system makes it an unusual enzyme since catalytic molecules are typically found in lesser amounts [104]. Overall, CaMKII plays a significant role in regulating neurotransmitter secretion, receptor function, axonal transport, and structural modifications of the cytoskeleton $[105,106]$.

CaMKII activation is dependent on calcium influx and the binding of $\mathrm{Ca}^{2+} / \mathrm{CaM}$ [102]. This complex binds to the regulatory region of CaMKII, producing a conformational change that not only leads to phosphorylation of target proteins, but also autophosphorylation, preventing the enzyme from reverting to its inactive conformation and decreasing the dissociation rate of bound CaM [103]. Thus, phosphorylated CaMKII acquires autonomous and $\mathrm{Ca}^{2+}$-independent activity and can become independent of $\mathrm{Ca}^{2+} / \mathrm{CaM}$ even after intracellular $\mathrm{Ca}^{2+}$ levels subside [107-109]. Functional alterations from autophosphorylation result, allowing $\mathrm{Ca}^{2+}$ to be translated into proper cellular responses. Autophosphorylation ramifications underlie the enzyme's complex autoregulatory behavior, enabling it to activate at various frequencies of calcium spikes, detect calcium spikes, and behave as a molecular switch in learning and memory, a readout of synaptic activity [99]. Due to its switch-like regulatory properties, CaMKII is highly touted as a sophisticated control over so many disparate cellular functions and has been proposed to be a primary molecular component in the etiology of AUDs and DDs [7,75].

\section{The Role of CaMKII in Alcohol Use Disorders}

The role of CaMKII in AUDs has not been extensively studied. However, some evidence indicates that CaMKII contributes to several AUD-related behaviors (Table 1). Alcohol self-administration increases phosphorylation of GluA1 at the CaMKII $\alpha$ recognition site (pGluA1- Ser831) in the central amygdala (CeA) of selectively bred alcohol-preferring P-rats as compared to behavior-matched (non-drug) sucrose controls. Intra-CeA injection of the AMPAR-positive modulator aniracetam or the cell-permeable CaMKII peptide inhibitor myristolated autocamtide-2-related inhibitory peptide (m-AIP), respectively, facilitated or inhibited alcohol self-administration [110]. Interestingly, CaMKII plays a different role in the aberrant behaviors induced by different doses of alcohol. In $\alpha$ CaMKII autophosphorylation-deficient $\alpha$ CaMKII-T286A mice, acute and subchronic administration of a low dose of alcohol $(2 \mathrm{~g} / \mathrm{kg}$, intraperitoneal injection, i.p.) failed to induce locomotion, but a high dose $(3.5 \mathrm{~g} / \mathrm{kg}$, i.p.) caused sedation. In $\alpha$ CaMKII-T286A mice, acute or subchronic alcohol administration did not change dopamine (DA) levels, measured by in vivo microdialysis, in the NAc, but enhanced serotonin (5-HT) responses in the prefrontal cortex were observed. Thus, $\alpha$ CaMKII autophosphorylation and the change in the DA-5-HT balance contribute to the establishment of alcohol-drinking behavior [111]. CaMKII may also act as a primary molecular mechanism that regulates relapse in alcohol addiction and cue-induced reinstatement of alcohol-seeking behavior, a hallmark behavioral pathology of addiction. In male C57BL/6J mice, reinstatement was associated with increased pCaMKII-T286 immunofluorescence reactive in specific reward- and memory-related brain regions, including the amygdala, NAc, lateral septum, mediodorsal thalamus, and piriform cortex, as compared with extinction control [112].

Importantly, CaMKII in the LHb plays a significant role in aversive behaviors during alcohol withdrawal $[7,58,110]$. The protein level of phosphorylated AMPAR GluA1 subunit at a CaMKII locus (pGluA1-Ser831) was higher in the LHb of Long-Evans rats withdrawn from chronic intermittent alcohol drinking compared with alcohol-naive rats. These alcohol-withdrawn rats showed clear depressive-like behaviors, measured by forced swimming test and sucrose-preferring test $[7,58,77]$, which were mitigated by intra-LHb injection of the AMPAR 
antagonist quinoxalinediones 6, 7-dinitroquinoxaline-2, 3-Dione (DNQX) or the CaMKII antagonist 1-[N,O-bis-(5-isoquinolinesulphonyl)-N-methyl-L-tyrosy]-4-phenylpiperazine (KN-62), or inhibiting $\mathrm{LHb}$ activity with a chemogenetic tool or deep brain stimulation $[7,113]$. Conversely, in alcohol-naive rats, activation of LHb AMPARs induced depressive-like behaviors [7].

CaMKII also takes part in pain hypersensitivity that often occurs in alcoholics and AUD animal models, especially during abstinence $[77,124,130]$. Chronic pain is a significant contributor in DD etiology [131-133]. In rats, the 5-HT receptors (5-HTRs) expressed on LHb neurons [58,134-136] and at the glutamatergic synapses on $\mathrm{LHb}$ neurons [137] contribute to nociception. Intra-LHb injection of meta-chlorophenylpiperazine (mCPP, a 5-HT2CR agonist) and 2,5-dimethoxy-4-iodoamphetamine (DOI, a 5-HT2A/2CR agonist) increased nociceptive sensitivity in alcohol naive rats, while antagonists SB200646 (a 5-HT2CR antagonist) and ritanserin (a 5-HT2A/2CR antagonist), 5-HT reuptake blocker citalopram, or CaMKII antagonist KN-62 mitigated the elevated nociceptive sensitivity in alcohol withdrawn rats [58].

An important facet to consider in understanding AUDs is glutamate, the primary excitatory neurotransmitter in the central nervous system. The N-methyl-D-aspartate receptors (NMDARs) and AMPARs are the two major subtypes of ionotropic glutamate receptors and are critical targets of alcohol. The NMDAR is a well-characterized target of ethanol that has been associated with both drinking behavior [138] and withdrawal [139]. Acute alcohol application inhibits NMDAR function in several preparations including recombinant heteromeric NMDA channels, NMDARs expressed in the oocytes [140,141], hippocampal neurons [142,143], cortical neurons [144], and neurons in the ventral bed nucleus of the stria terminalis (BNST) [145]. In contrast, chronic alcohol exposure leads to an upregulation of NMDAR function in several brain regions related to reward and memory [146,147], such as the BNST [123] and the dorsal striatum [138]. Chronic alcohol exposure, both in vivo and in vitro, increases the gene expression of NMDAR subunits NR1 and NR2B and their polypeptide levels [148]. Enhanced NMDAR activity significantly increases the amount of calcium that enters nerve cells. $\mathrm{Ca}^{2+}$ influx through NMDARs and subsequent activation of CaMKII are critical events in the induction of long-term potentiation, learning, and memory [149-153].

Similarly, the AMPARs also play an essential role in regulating synaptic strength [154] and AUDs $[7,155]$. The glutamate A1 (GluA1), one of the four subunits (GluA1-4) in the AMPARs, plays a particularly important role in AUDs $[7,110,125,156]$. The $\mathrm{LHb}$ receives robust glutamatergic inputs and expresses the GluA1 subunit predominantly [157]. It is worth mentioning the significant role of AMPAR activation in removing the voltage-dependent block by $\mathrm{Mg}^{2+}$ of NMDARs. During bouts of synaptic activity, AMPAR-mediated depolarization of the postsynaptic membrane facilitates the activation of NMDARs [158].

In Long-Evans rats, activation of CaMKII enhances glutamatergic transmission by phosphorylating serine 831 (Ser831) on the GluA1 subunit and by promoting AMPAR insertion into the synapse [7] (Figure 2). This enables AMPARs to play a critical role in regulating synaptic strength [159]. Site-specific phosphorylation has been studied extensively and is likely to be upregulated to increase AMPAR surface expression, thereby enhancing glutamatergic transmission. This is the key to understanding synaptic plasticity and addictive disorders, including AUDs $[7,160]$. The activation of AMPARs in $\mathrm{LHb}$ neurons promotes drug-taking episodes and vulnerability to relapse $[7,159]$. 
Table 1. Evidence on CaMKII in alcohol use disorders and its comorbidities.

\begin{tabular}{|c|c|c|c|c|c|}
\hline Brain Region & Alcohol Treatment & Tested In & CaMKII Levels & Findings & Reference \\
\hline \multirow{3}{*}{ Global } & $2 \mathrm{~g} / \mathrm{kg}$, i.p. & \multirow{3}{*}{$\begin{array}{c}\text { pCaMKII } \alpha \text {-deficient, } \\
\text { heterozygous, and WT mice }\end{array}$} & \multirow{3}{*}{ N/A } & $\begin{array}{l}\uparrow \text { EtOH's negative reinforcing action } \\
\text { in pCaMKII } \alpha \text {-deficient mice }\end{array}$ & [114] \\
\hline & Three-bottle free choice & & & $\begin{array}{l}\text { Onset of EtOH consumption delayed } \\
\text { in pCaMKII } \alpha \text {-deficient mice }\end{array}$ & [111] \\
\hline & & & & $\begin{array}{l}\text { pCaMKII is crucial to hippocampal } \\
\text { DG neuron activation after EtOH } \\
\text { exposure }\end{array}$ & [115] \\
\hline \multirow{3}{*}{ PFC } & Operant self-admin & C57BL/6J mice & CaMKII $\alpha(\uparrow)$ & $\begin{array}{l}\downarrow \mathrm{mPFC} \text { CaMKII } \uparrow \text { the positive } \\
\text { reinforcing effects of sweetened EtOH } \\
\text { pCaMKII in dorsal mPFC is }\end{array}$ & [116] \\
\hline & CIE & L-E rats $(\mathrm{M})$ & $\operatorname{CaMKII} \alpha(\uparrow)$ & $\begin{array}{l}\text { associated with EtOH-induced } \\
\text { cognitive inflexibility }\end{array}$ & [117] \\
\hline & Three-bottle free choice & Mice & $\operatorname{CaMKII} \alpha(\downarrow)$ & $\begin{array}{l}\text { PFC CaMkII } \alpha \text { gene is linked to EtOH } \\
\text { consumption }\end{array}$ & [118] \\
\hline $\mathrm{mPFC}$ and NAc Sh & Self-admin $(20 \%)(28 \mathrm{~d})$ & S-D rats $(\mathrm{M})$ & $\begin{array}{c}\text { pCaMKII }(\uparrow) \text { at } 6 \mathrm{~h} \\
\text { deprivation }\end{array}$ & $\begin{array}{c}\text { CaMKII mediates EtOH-WD-induced } \\
\text { anxiety and neurochemical } \\
\text { adaptations in mPFC and NAc }\end{array}$ & [119] \\
\hline \multirow{3}{*}{ NAc Sh } & CIE & Adult Wistar rats (M) & $\begin{array}{l}\text { pCaMKII }(\downarrow) \text { in high } \\
\text { responders }\end{array}$ & $\begin{array}{l}\downarrow \mathrm{pCaMKII} \text { is involved in } \\
\text { EtOH-seeking behaviors }\end{array}$ & [120] \\
\hline & Self-admin $(6 \%)(28 \mathrm{~d})$ & S-D rats $(\mathrm{M})$ & $\begin{array}{l}\text { pCaMKII CIE }(\downarrow) \\
24 \mathrm{~h} \mathrm{WD}(\uparrow)\end{array}$ & $\begin{array}{l}\text { Activation of NMDAR1-CaMKII } \\
\text { contributes to EtOH drinking and } \\
\text { negative emotional states }\end{array}$ & [121] \\
\hline & Drink in the dark (14 d) & $\begin{array}{l}\text { Adult and adolescent C57BL/6J } \\
\text { mice (M) }\end{array}$ & $\begin{array}{c}\text { CaMKII at } 24 \mathrm{~h} \text { WD } \\
\text { Adult }(\uparrow) \\
\text { Adolescent }(\leftrightarrow)\end{array}$ & $\begin{array}{c}\text { CaMKII is positively linked to } \\
\text { negative affective symptoms in } \\
\text { EtOH-WD adults }\end{array}$ & [122] \\
\hline BNST & $0.8 \mathrm{~g} / \mathrm{kg}$, i.p. + CIE & C57BL/6J mice $(\mathrm{M})$ & $\operatorname{CaMKII} \alpha(\downarrow)$ & $\begin{array}{c}\downarrow \text { CaMKII } \alpha \text { in EtOH-exposed vBNST } \\
\text { contributes to changes in synaptic } \\
\text { NMDAR kinetics }\end{array}$ & [123] \\
\hline $\begin{array}{l}\text { Amygdala, NAc, septum, } \\
\text { thalamus, piriform cortex }\end{array}$ & Self-admin & C57BL/6J mice $(\mathrm{M})$ & pCaMKII-T286 ( $\uparrow)$ & $\begin{array}{l}\text { Cue-induced reinstatement of } \\
\text { EtOH-seeking is associated with } \\
\text { pCaMKII-T286 in reward- and } \\
\text { memory-related brain regions }\end{array}$ & [112] \\
\hline
\end{tabular}


Table 1. Cont.

\begin{tabular}{|c|c|c|c|c|c|}
\hline Brain Region & Alcohol Treatment & Tested In & CaMKII Levels & Findings & Reference \\
\hline $\mathrm{LHb}$ & $\begin{array}{l}\text { Two-bottle free choice } \\
\qquad(8-12 \mathrm{w})\end{array}$ & S-D and L-E rats (M) & CaMKII ( () at $24 \mathrm{~h} \mathrm{WD}$ & $\begin{array}{l}\downarrow \mathrm{CaMKII} \text { in the } \mathrm{LHb} \downarrow \mathrm{EtOH} \text { intake } \\
\text { and depressive symptoms }\end{array}$ & {$[7,124]$} \\
\hline \multirow{3}{*}{ Amygdala } & Self-admin & Adult $P$ rats $(\mathrm{M})$ & $\begin{array}{l}\text { pCaMKII-T286 and } \\
\text { CaMKII } \alpha(\uparrow)\end{array}$ & $\begin{array}{l}\downarrow \text { Acb CaMKII } \downarrow \text { EtOH } \\
\text { self-administration }\end{array}$ & [110] \\
\hline & Operant self-admin (15\%) & Adult C57BL/6J mice (M) & pCaMKII ( $)$ & $\begin{array}{l}\text { EtOH drinking } \uparrow \text { CaMKII in the } \\
\text { amygdala that regulates EtOH's } \\
\text { positive reinforcing effects }\end{array}$ & [125] \\
\hline & $\begin{array}{l}\text { Home-cage drink and } \\
\text { operant self-admin }\end{array}$ & $\begin{array}{l}\text { Adolescent and adult C57BL/6J } \\
\text { mice }(\mathrm{M})\end{array}$ & $\begin{array}{l}\text { pCaMKII } \alpha-\mathrm{T} 286 \\
\text { Adolescent }(\downarrow) \\
\text { Adults }(\leftrightarrow)\end{array}$ & $\begin{array}{l}\text { Differential CaMKII } \alpha \text {-dependent } \\
\text { AMPAR activation underlies } \\
\text { age-related escalation of binge } \\
\text { drinking }\end{array}$ & [126] \\
\hline Basolateral amygdala & CIE & S-D rats $(\mathrm{M})$ & $\begin{array}{c}\text { pCaMKII-T286 } \\
\text { CIE }(\uparrow), W D(\leftrightarrow) \\
\text { pCaMKII-T305 } \\
\text { CIE }(\leftrightarrow), \text { WD }(\uparrow)\end{array}$ & $\begin{array}{l}\text { CIE- and WD-induced changes in } \\
\text { CaMKII activity contribute to } \uparrow \\
\text { GluA1R phosphorylation/trafficking }\end{array}$ & [127] \\
\hline $\begin{array}{l}\text { Hippocampal } \\
\text { CA1 and DG }\end{array}$ & Self-admin $(20 \%)(28 d)$ & S-D rats $(M)$ & $\begin{array}{c}\text { pCaMKII-T286 } \\
\text { CIE }(\downarrow) \\
\text { WD }(\uparrow)\end{array}$ & $\begin{array}{l}\text { CaMKII activation in hippocampal } \\
\text { subregions contributes to EtOH } \\
\text { dependence }\end{array}$ & [128] \\
\hline Cerebral cortex & Self-admin $(10 \%)$ & Wistar rats & $\operatorname{CaMKII} \alpha(\uparrow)$ & $\begin{array}{c}\text { Pre- and post-natal EtOH exposure } \uparrow \\
\text { CaMKII levels in membrane and } \\
\text { cytosolic fractions }\end{array}$ & [129] \\
\hline
\end{tabular}

$\uparrow$ indicate increase, $\downarrow$ decrease, $\leftrightarrow$ no change. AMPAR, AMPA receptor; CA1, hippocampal cornu ammonis 1; CIE, chronic intermittent ethanol exposure; DG, dentate gyrus; EtOH-WD, alcohol withdrawal; PFC, prefrontal cortex; i.p., intraperitoneal injection; L-E, Long-Evans rats; M, males; mPFC, medial prefrontal cortex; NAc Sh, nucleus accumbens shell; NMDAR,

NMDA receptor; $\mathrm{pCaMKII} \alpha$, alpha CaMKII autophosphorylation; P rats, alcohol-preferring rats; S-D, Sprague-Dawley; Self-admin, self-administration; vBNST, ventral bed nucleus of the stria terminalis; WD, withdrawal; WT, wild type; the concentrations of alcohol (EtOH), and the duration of alcohol treatment are in parenthesis. 
Chronic alcohol exposure increases surface concentrations of GluA1 in the striatum, promoting alcohol self-administration by modifying reinforcement processes [156]. Additionally, phosphorylation of GluA1 at Ser831 is significantly increased in the LHb of rats undergoing alcohol withdrawal, consistent with the findings that phosphorylation at this site increases AMPAR activity, thus reinforcing alcohol-drinking and alcohol-seeking behaviors [7]. On the other hand, local pharmacological inhibition of LHb AMPAR activity or blocking CaMKII signaling alleviated the depressive-like behaviors and alcohol-drinking behavior (Figure 2) [7]. However, insights about the input-specific expression and subcellular localization of these receptors are still lacking and require further investigation. The combinatorial use of genetic tools, optogenetic strategies, and electrophysiology will be necessary to refine our understanding of the LHb connectivity.

As mentioned, electrophysiological and behavioral evidence from rats also shows that adaptation in the serotonin (5-HT) 2 receptor-CaMKII signaling pathway contributes to the hyper-glutamatergic state, the hyperactivity of $\mathrm{LHb}$ neurons, and the higher nociceptive sensitivity in rats withdrawing from chronic alcohol consumption [124]. Through a combination of behavioral and molecular approaches, a study in the selectively bred alcohol-preferring (P) and alcohol-non-preferring (NP) lines of rats found that compared with NP rats, the P-rats had a higher sensitivity to mechanical stimuli and displayed depressive-like behaviors, as well as a higher level of CaMKII in the LHb, all of which were ameliorated by alcohol drinking [161]. CaMKII in the LHb plays a significant role not only in AUDs, but also in the other commonly abused drugs, such as morphine, as shown in a recent mouse study in which chronic morphine treatment resulted in CaMKII overexpression in the LHb [162].

\section{The Role of CaMKII in Depressive Disorders}

Depressive disorders (DDs) are one of the most widespread and incapacitating mental disorders, resulting in the loss of motivation and interest, feelings of despair, and the inability to feel pleasure [75]. Since $\mathrm{LHb}$ was recently discovered as the key brain region in the pathophysiology of depression, a surge in interest over CaMKII has uncovered its role in regulating several signal transduction pathways associated with learning and memory. Since it can remain activated beyond the timeframe of $\mathrm{Ca}^{2+}$ infiltration that initially stimulated molecule, CaMKII is often dubbed a "memory molecule" [102]. Stress-induced elevations in bCaMKII signaling, in particular, are related to depression because they influence the formation and retention of aversive memories [31].

Through a combination of electrophysiological, behavioral, and molecular approaches, the bCaMKII was identified as the key contributor for habenular hyperactivity and, thus, depressive-like behaviors. Recent studies have shown that amplification of bCaMKII function mediates increased depolarization of $\mathrm{LHb}$ neurons. When tested in rats and mice, overexpression of bCaMKII, but not $\alpha \mathrm{CaMKII}$, in the $\mathrm{LHb}$, using viral vectors (adeno-associated virus 2 (AAV2)) strongly enhanced the synaptic efficacy and spike output of $\mathrm{LHb}$ neurons and produced profound depressive symptoms, including anhedonia and behavioral despair, which were reversed by downregulation of $\beta$ CaMKII levels, blocking its activity or its target molecule glutamate A1 (GluR1) [75]. In contrast to chronic stress, acute stress has been shown to increase both isoforms, $\alpha$ CaMKII and bCaMKII [83]. Furthermore, an increase of bCaMKII enhanced the synaptic efficacy of LHb neurons, producing profound depressive-like symptoms. This could be because of elevated bCaMKII, strengthening AMPAR-mediated synaptic transmission and hyperactivity of the $\mathrm{LHb}$. On the other hand, blocking CaMKII activity, or its target molecule, GluA1, reversed depressive-like symptoms [75].

Additionally, bCaMKII may regulate other channels of $\mathrm{LHb}$ neurons that enhance spike output. An important question that has yet to be addressed is the feature that renders $\beta$ CaMKII sensitive to depressive stimuli and antidepressants [75]. This leads to speculation that $\beta$ CaMKII plays a significant role in $\mathrm{LHb}$ neuronal function and is a key determinant of depression [75]. That facilitation of glutamate transmission in the LHb may lead to depressive symptoms $[7,18,19,71,84,163]$ (Figures 1 and 2). Further support of this idea is the finding that ketamine, an NMDAR antagonist, suppresses the depressive-like behaviors in rodent models of depression [18]. The discovery of ketamine's rapid 
antidepressant effects is perhaps the most critical advance in the psychiatry field in recent history [164]. To investigate the underlying mechanisms, in a recent study, ketamine was applied into the LHb in rats, which quickly rescued depression-like behaviors. In vivo and ex vivo, electrophysiological recording found that burst firing, which was increased in the LHb of depressive rodent models, was suppressed by ketamine [18].

\section{The Comorbidity of Depressive Disorders and Alcohol Use Disorders}

Alcoholics have extremely high rates of co-occurring psychological disorders, including depressive disorders (DDs) [165-168]. Compared to non-alcoholics, alcohol-dependent Americans have 1.7-3.6 times the risk for major depression, and 7.1 times for other drug addictions [165,167]. Although the reasons for the comorbidity of AUDs and DDs remain unknown, DDs are almost invariably involved in developing AUDs, thereby weakening the effects of treatment and increasing the risk of relapse $[7,169]$. Nearly one-third of patients who present with the major depressive disorder also suffer from AUDs [170]. Studies in the general population have shown that people with depressive symptoms have a 2-3-fold increased risk of developing AUDs [171]. It is essential to understand the overlapping neural mechanisms behind these comorbidities.

An important facet to consider in understanding depression that is concomitant with AUDs is the AMPARs. Enhanced AMPAR signaling via CaMKII interaction with the GluA1 may be one of the pathophysiological changes that influence drug-taking and drug-seeking behaviors and produce a phenotype akin to that of an alcoholic [159]. Building on this idea, in a study in alcohol-withdrawing rats, which showed clear depressive-like symptoms, AMPARs and CaMKII in the $\mathrm{LHb}$ were increased. Inhibition of LHb AMPARs, CaMKII activity, and LHb neuronal activity significantly mitigated depressive-like behaviors and alcohol-drinking and alcohol-seeking behaviors. Conversely, activation of LHb AMPARs induced depressive-like symptoms [7]. These results suggest that the LHb CaMKII-AMPAR signaling pathway may be a potential target and provide a new therapeutic approach not only to relieve symptoms of depression, but also to alleviate the desire for alcohol consumption [7]. Thus, LHb hyperactivity and enhanced glutamatergic transmissions during both DD and AUD states may be the cellular and molecular mechanisms underlying LHb's role in the connection between depression and addiction. Building on the finding of the significant antidepressant effect of the NMDAR antagonist ketamine, interest in the effect of ketamine on AUDs is growing and has shown promising results. In humans, ketamine reduced harmful drinking by pharmacologically rewriting drinking memories [172]. In adult Wistar male rats, both ketamine and 2,3-Dihydroxy-6-nitro-7-sulphamoylbenzo(f)-quinoxaline, 6-Nitro-7-sulphamoylbenzo(f)-quinoxaline-2,3-dione (NBQX), (daily intraperitoneal injections of ketamine $(2.5 \mathrm{mg} / \mathrm{kg})$ and NBQX $(5 \mathrm{mg} / \mathrm{kg})$, alone or in combination) attenuated alcohol-withdrawal induced depression, measured by forced swim test [173]. These data provide further support for the connection between AUDs and DDs. Future studies on the effect of LHb application of ketamine and other NMDAR antagonists on the comorbidities of AUDs and DDs will further reveal the role of LHb in the connection between DDs and AUDs (Figure 2).

\section{Conclusions}

Depressive disorders concomitant with alcohol use disorders reinforce each other. Together, they are often challenging to treat, as relapse in one quickly leads to relapse in the other, and the symptoms overlap. As reviewed in this article, both depressive disorders and alcohol use disorders can cause LHb hyperactivity, which inhibits the activity of dopamine neurons and serotonin neurons in the midbrain reward center. The hypofunction of these midbrain neurons is believed to be a significant cause of psychological disorders. Both alcohol use disorders and depressive disorders increase glutamate transmission to the LHb neurons and, consequently, the activation of AMPARs and NMDARs, among others. The increased calcium influx through NMDARs activates CaMKII, a key molecule in the pathophysiology of both alcohol use disorders and depressive disorders. Since CaMKII 
in the LHb plays a prominent role in depression and addiction, it is expected that further study of the pathophysiology involved will allow for the development of targeted therapies to address the comorbidities.

Funding: This research is made possible by grants from National Institutes of Health, US to J.-H.Y.

Conflicts of Interest: The authors declare no conflict of interest.

\section{References}

1. Sacks, J.J.; Gonzales, K.R.; Bouchery, E.E.; Tomedi, L.E.; Brewer, R.D. 2010 national and state costs of excessive alcohol consumption. Am. J. Prev. Med. 2015, 49, e73-e79. [CrossRef] [PubMed]

2. Ripke, S.; Wray, N.R.; Lewis, C.M.; Hamilton, S.P.; Weissman, M.M.; Breen, G.; Byrne, E.M.; Blackwood, D.H.R.; Boomsma, D.I.; Cichon, S.; et al. Major Depressive Disorder Working Group of the Psychiatric, G.C. A mega-analysis of genome-wide association studies for major depressive disorder. Mol. Psychiatry 2013, 18, 497-511. [PubMed]

3. Cassano, P.; Fava, M. Depression and public health, and overview. J.Psychosom. Res. 2002, 53, 849-857. [CrossRef]

4. Burns, L.; Teesson, M. Alcohol use disorders comorbid with anxiety, depression and drug use disorders. Findings from the Australian National Survey of Mental Health and Well Being. Drug Alcohol Depend. 2002, 68, 299-307. [CrossRef]

5. Petrakis, I.L.; Gonzalez, G.; Rosenheck, R.; Krystal, J.H. Comorbidity of alcoholism and psychiatric disorders: An overview. Alcohol Res. Health 2002, 26, 81-89.

6. Akbar, M.; Egli, M.; Cho, Y.E.; Song, B.J.; Noronha, A. Medications for alcohol use disorders: An overview. Pharmacy 2018, 185, 64-85. [CrossRef]

7. Li, J.; Kang, S.; Fu, R.; Wu, L.; Wu, W.; Liu, H.; Gregor, D.; Zuo, W.; Bekker, A.; Ye, J.H. Inhibition of AMPA receptor and CaMKII activity in the lateral habenula reduces depressive-like behavior and alcohol intake in rats. Neuropharmacology 2017, 126, 108-120. [CrossRef]

8. Hikosaka, O. The habenula: From stress evasion to value-based decision-making. Nat. Rev. Neurosci 2010, 11, 503-513. [CrossRef]

9. Aizawa, H.; Amo, R.; Okamoto, H. Phylogeny and ontogeny of the habenular structure. Front. Neurosci. 2011, 5, 138. [CrossRef]

10. Namboodiri, V.M.; Rodriguez-Romaguera, J.; Stuber, G.D. The habenula. Curr. Biol. 2016, 26, R873-R877. [CrossRef] [PubMed]

11. Geisler, S.; Trimble, M. The lateral habenula: No longer neglected. CNS Spectr. 2008, 13, 484-489. [CrossRef] [PubMed]

12. Sartorius, A.; Kiening, K.L.; Kirsch, P.; von Gall, C.C.; Haberkorn, U.; Unterberg, A.W.; Henn, F.A.; Meyer-Lindenberg, A. Remission of major depression under deep brain stimulation of the lateral habenula in a therapy-refractory patient. Biol. Psychiatry 2010, 67, e9-e11. [CrossRef] [PubMed]

13. Li, B.; Piriz, J.; Mirrione, M.; Chung, C.; Proulx, C.D.; Schulz, D.; Henn, F.; Malinow, R. Synaptic potentiation onto habenula neurons in the learned helplessness model of depression. Nature 2011, 470, 535-539. [CrossRef]

14. Shabel, S.J.; Proulx, C.D.; Piriz, J.; Malinow, R. Mood regulation. GABA/glutamate co-release controls habenula output and is modified by antidepressant treatment. Science 2014, 345, 1494-1498. [CrossRef] [PubMed]

15. Lecca, S.; Pelosi, A.; Tchenio, A.; Moutkine, I.; Lujan, R.; Hervé, D.; Mameli, M. Rescue of GABAB and GIRK function in the lateral habenula by protein phosphatase $2 \mathrm{~A}$ inhibition ameliorates depression-like phenotypes in mice. Nat. Med. 2016, 22, 254-261. [CrossRef]

16. Tchenio, A.; Lecca, S.; Valentinova, K.; Mameli, M. Limiting habenular hyperactivity ameliorates maternal separation-driven depressive-like symptoms. Nat. Commun. 2017, 8, 1135. [CrossRef]

17. Cui, Y.; Yang, Y.; Ni, Z.; Dong, Y.; Cai, G.; Foncelle, A.; Ma, S.; Sang, K.; Tang, S.; Li, Y.; et al. Astroglial Kir4.1 in the lateral habenula drives neuronal bursts in depression. Nature 2018, 554, 323-327. [CrossRef]

18. Yang, Y.; Cui, Y.; Sang, K.; Dong, Y.; Ni, Z.; Ma, S.; Hu, H. Ketamine blocks bursting in the lateral habenula to rapidly relieve depression. Nature 2018, 554, 317-322. [CrossRef] 
19. Yang, Y.; Wang, H.; Hu, J.; Hu, H. Lateral habenula in the pathophysiology of depression. Curr. Opin. Neurobiol. 2018, 48, 90-96. [CrossRef]

20. Wang, R.Y.; Aghajanian, G.K. Physiological evidence for habenula as major link between forebrain and midbrain raphe. Science 1977, 197, 89-91. [CrossRef]

21. Christoph, G.R.; Leonzio, R.J.; Wilcox, K.S. Stimulation of the lateral habenula inhibits dopamine-containing neurons in the substantia nigra and ventral tegmental area of the rat. J. Neurosci. 1986, 6, 613-619. [CrossRef] [PubMed]

22. Varga, V.; Kocsis, B.; Sharp, T. Electrophysiological evidence for convergence of inputs from the medial prefrontal cortex and lateral habenula on single neurons in the dorsal raphe nucleus. Eur. J. Neurosci. 2003, 17, 280-286. [CrossRef]

23. Velasquez, K.; Molfese, D.; Salas, R. The role of the habenula in drug addiction. Front. Hum. Neurosci. 2014, 8, 174. [CrossRef]

24. Zhao, H.; Zhang, B.-L.; Yang, S.-J.; Rusak, B. The role of lateral habenula-dorsal raphe nucleus circuits in higher brain functions and psychiatric illness. Behav. Brain Res. 2015, 277, 89-98. [CrossRef] [PubMed]

25. Keiflin, R.; Janak, P.H. Dopamine prediction errors in reward learning and addiction: From theory to neural circuitry. Neuron 2015, 88, 247-263. [CrossRef]

26. Hu, H.; Cui, Y.; Yang, Y. Circuits and functions of the lateral habenula in health and in disease. Nat. Rev. Neurosci. 2020, 21, 277-295. [CrossRef] [PubMed]

27. Jhou, T.C.; Fields, H.L.; Baxter, M.G.; Saper, C.B.; Holland, P.C. The rostromedial tegmental nucleus (RMTg), a GABAergic afferent to midbrain dopamine neurons, encodes aversive stimuli and inhibits motor responses. Neuron 2009, 61, 786-800. [CrossRef]

28. Kaufling, J.; Veinante, P.; Pawlowski, S.A.; Freund-Mercier, M.J.; Barrot, M. Afferents to the GABAergic tail of the ventral tegmental area in the rat. J. Comp. Neurol. 2009, 513, 597-621. [CrossRef]

29. Lecourtier, L.; Defrancesco, A.; Moghaddam, B. Differential tonic influence of lateral habenula on prefrontal cortex and nucleus accumbens dopamine release. Eur. J. Neurosci. 2008, 27, 1755-1762. [CrossRef]

30. Lammel, S.; Lim, B.K.; Ran, C.; Huang, K.W.; Betley, M.J.; Tye, K.M.; Deisseroth, K.; Malenka, R.C. Input-specific control of reward and aversion in the ventral tegmental area. Nature 2012, 491, $212-217$. [CrossRef]

31. Browne, C.A.; Hammack, R.; Lucki, I. Dysregulation of the lateral habenula in major depressive disorder. Front. Synaptic Neurosci. 2018, 10, 46. [CrossRef] [PubMed]

32. Omelchenko, N.; Bell, R.; Sesack, S.R. Lateral habenula projections to dopamine and GABA neurons in the rat ventral tegmental area. Eur. J. Neurosci. 2009, 30, 1239-1250. [CrossRef] [PubMed]

33. Proulx, C.D.; Aronson, S.; Milivojevic, D.; Molina, C.; Loi, A.; Monk, B.; Shabel, S.J.; Malinow, R. A neural pathway controlling motivation to exert effort. Proc. Natl. Acad. Sci. USA 2018, 115, 5792-5797. [CrossRef]

34. Proulx, C.D.; Hikosaka, O.; Malinow, R. Reward processing by the lateral habenula in normal and depressive behaviors. Nat. Neurosci. 2014, 17, 1146-1152. [CrossRef] [PubMed]

35. Root, D.H.; Melendez, R.I.; Zaborszky, L.; Napier, T.C. The ventral pallidum: Subregion-specific functional anatomy and roles in motivated behaviors. Prog. Neurobiol. 2015, 130, 29-70. [CrossRef]

36. Stamatakis, A.M.; Stuber, G.D. Activation of lateral habenula inputs to the ventral midbrain promotes behavioral avoidance. Nat. Neurosci. 2012, 15, 1105-1107. [CrossRef] [PubMed]

37. Lecca, S.; Meye, F.J.; Mameli, M. The lateral habenula in addiction and depression: An anatomical, synaptic and behavioral overview. Eur. J. Neurosci. 2014, 39, 1170-1178. [CrossRef]

38. Matsumoto, M.; Hikosaka, O. Lateral habenula as a source of negative reward signals in dopamine neurons. Nature 2007, 447, 1111-1115. [CrossRef]

39. Volkow, N.D.; Fowler, J.S.; Wang, G.-J.; Swanson, J.M.; Telang, F. Dopamine in drug abuse and addiction: Results of imaging studies and treatment implications. Arch. Neurol. 2007, 64, 1575-1579. [CrossRef]

40. Diana, M. The dopamine hypothesis of drug addiction and its potential therapeutic value. Front. Psychiatry 2011, 2, 64. [CrossRef]

41. Wise, R.A.; Robble, M.A. Dopamine and addiction. Annu. Rev. Psychol. 2020, 71, 79-106. [CrossRef]

42. You, C.; Vandegrift, B.; Brodie, M.S. Ethanol actions on the ventral tegmental area: Novel potential targets on reward pathway neurons. Psychopharmacol. 2018, 235, 1711-1726. [CrossRef]

43. Wise, R.A.; Rompre, P.-P. Brain dopamine and reward. Annu. Rev. Psychol. 1989, 40, 191-225. [CrossRef] [PubMed] 
44. Pignatelli, M.; Bonci, A. Role of dopamine neurons in reward and aversion: A synaptic plasticity perspective. Neuron 2015, 86, 1145-1157. [CrossRef] [PubMed]

45. Graziane, N.M.; Neumann, P.A.; Dong, Y. A Focus on reward prediction and the lateral habenula: Functional alterations and the behavioral outcomes induced by drugs of abuse. Front. Synaptic Neurosci. 2018, 10, 12. [CrossRef]

46. Faulkner, P.; Deakin, J.F. The role of serotonin in reward, punishment and behavioural inhibition in humans: Insights from studies with acute tryptophan depletion. Neurosci. Biobehav. Rev. 2014, 46, 365-378. [CrossRef]

47. Müller, C.P.; Homberg, J.R. The role of serotonin in drug use and addiction. Behav. Brain Res. 2015, 277, 146-192. [CrossRef]

48. Cannon, D.M.; Ichise, M.; Rollis, D.; Klaver, J.M.; Gandhi, S.K.; Charney, D.S.; Manji, H.K.; Drevets, W.C. Elevated serotonin transporter binding in major depressive disorder assessed using positron emission tomography and [11C] DASB.; Comparison with bipolar disorder. Biol. Psychiatry 2007, 62, 870-877. [CrossRef]

49. Bernard, R.; Veh, R.W. Individual neurons in the rat lateral habenular complex project mostly to the dopaminergic ventral tegmental area or to the serotonergic raphe nuclei. J. Comp. Neurol. 2012, 520, 2545-2558. [CrossRef] [PubMed]

50. Quina, L.A.; Tempest, L.; Ng, L.; Harris, J.A.; Ferguson, S.; Jhou, T.C.; Turner, E.E. Efferent pathways of the mouse lateral habenula. J. Comp. Neurol. 2015, 523, 32-60. [CrossRef]

51. Pollak Dorocic, I.; Fürth, D.; Xuan, Y.; Johansson, Y.; Pozzi, L.; Silberberg, G.; Carlén, M.; Meletis, K. A whole-brain atlas of inputs to serotonergic neurons of the dorsal and median raphe nuclei. Neuron 2014, 83, 663-678. [CrossRef]

52. Weissbourd, B.; Ren, J.; DeLoach, K.E.; Guenthner, C.J.; Miyamichi, K.; Luo, L. Presynaptic partners of dorsal raphe serotonergic and GABAergic neurons. Neuron 2014, 83, 645-662. [CrossRef]

53. Vertes, R.P.; Fortin, W.J.; Crane, A.M. Projections of the median raphe nucleus in the rat. J. Comp. Neurol. 1999, 407, 555-582. [CrossRef]

54. Vertes, R.P. A PHA-L analysis of ascending projections of the dorsal raphe nucleus in the rat. J. Comp. Neurol. 1991, 313, 643-668. [CrossRef]

55. Morin, L.P.; Meyer-Bernstein, E.L. The ascending serotonergic system in the hamster: Comparison with projections of the dorsal and median raphe nuclei. Neuroscience 1999, 91, 81-105. [CrossRef]

56. Muzerelle, A.; Scotto-Lomassese, S.; Bernard, J.F.; Soiza-Reilly, M.; Gaspar, P. Conditional anterograde tracing reveals distinct targeting of individual serotonin cell groups (B5-B9) to the forebrain and brainstem. Brain Struct. Funct. 2016, 221, 535-561. [CrossRef] [PubMed]

57. Kiyasova, V.; Fernandez, S.P.; Laine, J.; Stankovski, L.; Muzerelle, A.; Doly, S.; Gaspar, P. A genetically defined morphologically and functionally unique subset of 5-HT neurons in the mouse raphe nuclei. J. Neurosci. 2011, 31, 2756-2768. [CrossRef]

58. Fu, R.; Zuo, W.; Shiwalkar, N.; Mei, Q.; Fan, Q.; Chen, X.; Li, J.; Bekker, A.; Ye, J.H. Alcohol withdrawal drives depressive behaviors by activating neurons in the rostromedial tegmental nucleus. Neuropsychopharmacology 2019, 44, 1464-1475. [CrossRef]

59. Geisler, S.; Andres, K.H.; Veh, R.W. Morphologic and cytochemical criteria for the identification and delineation of individual subnuclei within the lateral habenular complex of the rat. J. Comp. Neurol. 2003, 458, 78-97. [CrossRef]

60. Zhang, L.; Hernández, V.S.; Vázquez-Juárez, E.; Chay, F.K.; Barrio, R.A. Thirst is associated with suppression of habenula output and active stress coping: Is there a role for a non-canonical vasopressin-glutamate pathway? Front. Neural Circuits 2016, 10, 13. [CrossRef]

61. Tchenio, A.; Valentinova, K.; Mameli, M. Can the lateral habenula crack the serotonin code? Front. Synaptic Neurosci. 2016, 8, 34. [CrossRef] [PubMed]

62. Aizawa, H.; Kobayashi, M.; Tanaka, S.; Fukai, T.; Okamoto, H. Molecular characterization of the subnuclei in rat habenula. J. Comp. Neurol. 2012, 520, 4051-4066. [CrossRef] [PubMed]

63. Aizawa, H.; Bianco, I.H.; Hamaoka, T.; Miyashita, T.; Uemura, O.; Concha, M.L.; Russell, C.; Wilson, S.W.; Okamoto, H. Laterotopic representation of left-right information onto the dorso-ventral axis of a zebrafish midbrain target nucleus. Curr. Biol. 2005, 15, 238-243. [CrossRef]

64. Ji, H.; Shepard, P.D. Lateral habenula stimulation inhibits rat midbrain dopamine neurons through a GABA(A) receptor-mediated mechanism. J. Neurosci. 2007, 27, 6923-6930. [CrossRef] 
65. Tian, J.; Uchida, N. Habenula lesions reveal that multiple mechanisms underlie dopamine prediction errors. Neuron 2015, 87, 1304-1316. [CrossRef] [PubMed]

66. Zhou, L.; Liu, M.-Z.; Li, Q.; Deng, J.; Mu, D.; Sun, Y.-G. Organization of functional long-range circuits controlling the activity of serotonergic neurons in the dorsal raphe nucleus. Cell Rep. 2017, 18, 3018-3032. [CrossRef]

67. Kang, S.; Li, J.; Zuo, W.; Fu, R.; Gregor, D.; Krnjevic, K.; Bekker, A.; Ye, J.-H. Ethanol withdrawal drives anxiety-related behaviors by reducing $\mathrm{m}$-type potassium channel activity in the lateral habenula. Neuropsychopharmacology 2017, 42, 1813-1824. [CrossRef]

68. Gonçalves, L.; Sego, C.; Metzger, M. Differential projections from the lateral habenula to the rostromedial tegmental nucleus and ventral tegmental area in the rat. J. Comp. Neurol. 2012, 520, 1278-1300. [CrossRef]

69. Sego, C.; Gonçalves, L.; Lima, L.; Furigo, I.C.; Donato, J., Jr.; Metzger, M. Lateral habenula and the rostromedial tegmental nucleus innervate neurochemically distinct subdivisions of the dorsal raphe nucleus in the rat. J. Comp. Neurol. 2014, 522, 1454-1484. [CrossRef]

70. Sun, Y.; Cao, J.; Xu, C.; Liu, X.; Wang, Z.; Zhao, H. Rostromedial tegmental nucleus-substantia nigra pars compacta circuit mediates aversive and despair behavior in mice. Exp. Neurol. 2020, 333, 113433. [CrossRef]

71. Kang, S.; Li, J.; Bekker, A.; Ye, J.H. Rescue of glutamate transport in the lateral habenula alleviates depressionand anxiety-like behaviors in ethanol-withdrawn rats. Neuropharmacology 2018, 129, 47-56. [CrossRef]

72. Zuo, W.; Fu, R.; Hopf, F.W.; Xie, G.; Krnjević, K.; Li, J.; Ye, J.H. Ethanol drives aversive conditioning through dopamine 1 receptor and glutamate receptor-mediated activation of lateral habenula neurons. Addict. Biol. 2017, 22, 103-116. [CrossRef] [PubMed]

73. Morris, J.; Smith, K.; Cowen, P.; Friston, K.; Dolan, R.J. Covariation of activity in habenula and dorsal raphe nuclei following tryptophan depletion. Neuroimage 1999, 10, 163-172. [CrossRef] [PubMed]

74. Shumake, J.; Edwards, E.; Gonzalez-Lima, F. Opposite metabolic changes in the habenula and ventral tegmental area of a genetic model of helpless behavior. Brain Res. 2003, 963, 274-281. [CrossRef]

75. Li, K.; Zhou, T.; Liao, L.; Yang, Z.; Wong, C.; Henn, F.; Malinow, R.; Yates, J.R., III; Hu, H. $\beta$ CaMKII in lateral habenula mediates core symptoms of depression. Science 2013, 341, 1016-1020. [CrossRef] [PubMed]

76. Lawson, R.P.; Drevets, W.C.; Roiser, J.P. Defining the habenula in human neuroimaging studies. Neuroimage 2013, 64, 722-727. [CrossRef] [PubMed]

77. Kang, S.; Li, J.; Zuo, W.; Chen, P.; Gregor, D.; Fu, R.; Han, X.; Bekker, A.; Ye, J.H. Downregulation of M-channels in lateral habenula mediates hyperalgesia during alcohol withdrawal in rats. Sci. Rep. 2019, 9, 2714. [CrossRef]

78. Yang, L.-M.; Hu, B.; Xia, Y.-H.; Zhang, B.-L.; Zhao, H. Lateral habenula lesions improve the behavioral response in depressed rats via increasing the serotonin level in dorsal raphe nucleus. Behav. Brain Res. 2008, 188, 84-90. [CrossRef]

79. Meng, H.; Wang, Y.; Huang, M.; Lin, W.; Wang, S.; Zhang, B. Chronic deep brain stimulation of the lateral habenula nucleus in a rat model of depression. Brain Res. 2011, 1422, 32-38. [CrossRef]

80. Winter, C.; Vollmayr, B.; Djodari-Irani, A.; Klein, J.; Sartorius, A. Pharmacological inhibition of the lateral habenula improves depressive-like behavior in an animal model of treatment resistant depression. Behav. Brain Res. 2011, 216, 463-465. [CrossRef]

81. Shabel, S.J.; Wang, C.; Monk, B.; Aronson, S.; Malinow, R. Stress transforms lateral habenula reward responses into punishment signals. Proc. Natl. Acad. Sci. USA 2019, 116, 12488-12493. [CrossRef]

82. Wirtshafter, D.; Asin, K.E.; Pitzer, M.R. Dopamine agonists and stress produce different patterns of Fos-like immunoreactivity in the lateral habenula. Brain Res. 1994, 633, 21-26. [CrossRef]

83. Park, H.; Rhee, J.; Park, K.; Han, J.-S.; Malinow, R.; Chung, C. Exposure to stressors facilitates long-term synaptic potentiation in the lateral habenula. J. Neurosci. 2017, 37, 6021-6030. [CrossRef] [PubMed]

84. Gregor, D.M.; Zuo, W.; Fu, R.; Bekker, A.; Ye, J.H. Elevation of transient receptor potential vanilloid 1 function in the lateral habenula mediates aversive behaviors in alcohol-withdrawn rats. Anesthesiology 2019, 130, 592-608. [CrossRef] [PubMed]

85. Volkow, N.D.; Fowler, J.S.; Wang, G.J.; Swanson, J.M. Dopamine in drug abuse and addiction: Results from imaging studies and treatment implications. Mol. Psychiatry 2004, 9, 557-569. [CrossRef]

86. Volkow, N.D.; Fowler, J.S.; Wang, G.J.; Baler, R.; Telang, F. Imaging dopamine's role in drug abuse and addiction. Neuropharmacology 2009, 56, 3-8. [CrossRef] 
87. Spanagel, R. Alcoholism: A systems approach from molecular physiology to addictive behavior. Physiol. Rev. 2009, 89, 649-705. [CrossRef] [PubMed]

88. Jhou, T.C.; Good, C.H.; Rowley, C.S.; Xu, S.P.; Wang, H.; Burnham, N.W.; Hoffman, A.F.; Lupica, C.R.; Ikemoto, $\mathrm{S}$. Cocaine drives aversive conditioning via delayed activation of dopamine-responsive habenular and midbrain pathways. J. Neurosci. 2013, 33, 7501-7512. [CrossRef]

89. Nowak, K.L.; McBride, W.J.; Lumeng, L.; Li, T.K.; Murphy, J.M. Involvement of dopamine D2 autoreceptors in the ventral tegmental area on alcohol and saccharin intake of the alcohol-preferring P rat. Alcohol Clin. Exp. Res. 2000, 24, 476-483. [CrossRef]

90. Gonzales, R.A.; Job, M.O.; Doyon, W.M. The role of mesolimbic dopamine in the development and maintenance of ethanol reinforcement. Pharmacol. Ther. 2004, 103, 121-146. [CrossRef]

91. Koob, G.F.; Volkow, N.D. Neurocircuitry of addiction. Neuropsychopharmacology 2010, 35, 217-238. [CrossRef] [PubMed]

92. Diana, M.; Pistis, M.; Muntoni, A.; Rossetti, Z.L.; Gessa, G. Marked decrease of A10 dopamine neuronal firing during ethanol withdrawal syndrome in rats. Eur. J. Pharmacol. 1992, 221, 403-404. [CrossRef]

93. Diana, M.; Pistis, M.; Carboni, S.; Gessa, G.L.; Rossetti, Z.L. Profound decrement of mesolimbic dopaminergic neuronal activity during ethanol withdrawal syndrome in rats: Electrophysiological and biochemical evidence. Proc. Natl. Acad. Sci. USA 1993, 90, 7966-7969. [CrossRef] [PubMed]

94. Shen, R.Y. Ethanol withdrawal reduces the number of spontaneously active ventral tegmental area dopamine neurons in conscious animals. J. Pharm. Exp. 2003, 307, 566-572. [CrossRef] [PubMed]

95. Weiss, F.; Parsons, L.H.; Schulteis, G.; Hyytiä, P.; Lorang, M.T.; Bloom, F.E.; Koob, G.F. Ethanol self-administration restores withdrawal-associated deficiencies in accumbal dopamine and 5-hydroxytryptamine release in dependent rats. J. Neurosci. 1996, 16, 3474-3485. [CrossRef] [PubMed]

96. Barak, S.; Carnicella, S.; Yowell, Q.V.; Ron, D. Glial cell line-derived neurotrophic factor reverses alcohol-induced allostasis of the mesolimbic dopaminergic system: Implications for alcohol reward and seeking. J. Neurosci. 2011, 31, 9885-9894. [CrossRef]

97. Szczypiński, J.J.; Gola, M. Dopamine dysregulation hypothesis: The common basis for motivational anhedonia in major depressive disorder and schizophrenia? Rev. Neurosci. 2018, 29, 727-744. [CrossRef]

98. Belujon, P.; Grace, A.A. Dopamine system dysregulation in major depressive disorders. Int. J. Neuropsychopharmacol. 2017, 20, 1036-1046. [CrossRef]

99. Hudmon, A.; Schulman, H. Structure-function of the multifunctional $\mathrm{Ca}^{2+} /$ calmodulin-dependent protein $^{2}$ kinase II. Biochem. J. 2002, 364, 593-611. [CrossRef]

100. Clapham, D.E. Calcium signaling. Cell 2007, 131, 1047-1058. [CrossRef]

101. Yamauchi, T. Neuronal $\mathrm{Ca}^{2+} /$ calmodulin-dependent protein kinase II-Discovery, progress in a quarter of a century, and perspective: Implication for learning and memory. Biol. Pharm. Bull. 2005, 28, 1342-1354. [CrossRef]

102. Swulius, M.; Waxham, M. $\mathrm{Ca}^{2+} /$ Calmodulin-dependent Protein Kinases. Cell. Mol. Life Sci. 2008, 65, 2637-2657. [CrossRef]

103. Zalcman, G.; Federman, N.; Romano, A. CaMKII isoforms in learning and memory: Localization and function. Front. Mol. Neurosci. 2018, 11, 445. [CrossRef]

104. Griffith, L.C. Calcium/calmodulin-dependent protein kinase II: An unforgettable kinase. J. Neurosci. 2004, 24, 8391-8393. [CrossRef]

105. Soderling, T.R.; Stull, J.T. Structure and regulation of calcium/calmodulin-dependent protein kinases. Chem. Rev. 2001, 101, 2341-2352. [CrossRef] [PubMed]

106. Colbran, R.J. Protein phosphatases and calcium/calmodulin-dependent protein kinase ii-dependent synaptic plasticity. J. Neurosci. 2004, 24, 8404-8409. [CrossRef]

107. Braun, A.P.; Schulman, H. The multifunctional calcium/calmodulin-dependent protein kinase: From form to function. Annu. Rev. Physiol. 1995, 57, 417-445. [CrossRef]

108. Colbran, R.J.; Brown, A.M. Calcium/calmodulin-dependent protein kinase II and synaptic plasticity. Curr. Opin. Neurobiol. 2004, 14, 318-327. [CrossRef] [PubMed]

109. Coultrap, S.J.; Buard, I.; Kulbe, J.R.; Dell'Acqua, M.L.; Bayer, K.U. CaMKII autonomy is substrate-dependent and further stimulated by $\mathrm{Ca}^{2+} /$ calmodulin. J. Biol. Chem. 2010, 285, 17930-17937. [CrossRef] 
110. Cannady, R.; Fisher, K.R.; Graham, C.; Crayle, J.; Besheer, J.; Hodge, C.W. Potentiation of amygdala AMPA receptor activity selectively promotes escalated alcohol self-administration in a CaMKII-dependent manner. Addict. Biol. 2017, 22, 652-664. [CrossRef] [PubMed]

111. Easton, A.C.; Lucchesi, W.; Lourdusamy, A.; Lenz, B.; Solati, J.; Golub, Y.; Lewczuk, P.; Fernandes, C.; Desrivieres, S.; Dawirs, R.R.; et al. $\alpha$ CaMKII autophosphorylation controls the establishment of alcohol drinking behavior. Neuropsychopharmacology 2013, 38, 1636-1647. [CrossRef] [PubMed]

112. Salling, M.C.; Hodge, C.J.; Psilos, K.E.; Eastman, V.R.; Faccidomo, S.P.; Hodge, C.W. Cue-induced reinstatement of alcohol-seeking behavior is associated with increased CaMKII T286 phosphorylation in the reward pathway of mice. Pharm. Biochem. Behav. 2017, 163, 20-29. [CrossRef] [PubMed]

113. Li, J.; Zuo, W.; Fu, R.; Xie, G.; Kaur, A.; Bekker, A.; Ye, J.H. High Frequency electrical stimulation of lateral habenula reduces voluntary ethanol consumption in rats. Int. J. Neuropsychopharmacol. 2016, 19, 10. [CrossRef]

114. Easton, A.C.; Lucchesi, W.; Mizuno, K.; Fernandes, C.; Schumann, G.; Giese, K.P.; Muller, C.P. alphaCaMKII autophosphorylation controls the establishment of alcohol-induced conditioned place preference in mice. Behav. Brain. Res. 2013, 252, 72-76. [CrossRef] [PubMed]

115. Schopf, I.; Easton, A.C.; Solati, J.; Golub, Y.; Kornhuber, J.; Giese, K.P.; Muller, C.P. alphaCaMKII autophosphorylation mediates neuronal activation in the hippocampal dentate gyrus after alcohol and cocaine in mice. Neurosci. Lett. 2015, 591, 65-68. [CrossRef]

116. Faccidomo, S.; Reid, G.T.; Agoglia, A.E.; Ademola, S.A.; Hodge, C.W. CaMKII inhibition in the prefrontal cortex specifically increases the positive reinforcing effects of sweetened alcohol in C57BL/6J mice. Behav. Brain Res. 2016, 298, 286-290. [CrossRef]

117. Natividad, L.A.; Steinman, M.Q.; Laredo, S.A.; Irimia, C.; Polis, I.Y.; Lintz, R.; Buczynski, M.W.; Martin-Fardon, R.; Roberto, M.; Parsons, L.H. Phosphorylation of calcium/calmodulin-dependent protein kinase II in the rat dorsal medial prefrontal cortex is associated with alcohol-induced cognitive inflexibility. Addict. Biol. 2018, 23, 1117-1129. [CrossRef]

118. de Paiva Lima, C.; da Silva, E.S.D.A.; Damasceno, S.; Ribeiro, A.F.; Rocha, C.S.; Berenguer de Matos, A.H.; Correia, D.; Boerngen-Lacerda, R.; Brunialti Godard, A.L. Loss of control over the ethanol consumption: Differential transcriptional regulation in prefrontal cortex. J. Neurogenet. 2017, 31, 170-177. [CrossRef]

119. Yuanyuan, J.; Junyan, Z.; Cuola, D.; Jingjing, C.; Yuhui, S.; Dan, X.; Wei, D.; Yongsheng, Z. Memantine attenuated alcohol withdrawal-induced anxiety-like behaviors through down-regulating NR1-CaMKII-ERK signaling pathway. Neurosci. Lett. 2018, 686, 133-139. [CrossRef]

120. Somkuwar, S.S.; Mandyam, C.D. Individual differences in ethanol drinking and seeking behaviors in rats exposed to chronic intermittent ethanol vapor exposure is associated with altered CaMKII autophosphorylation in the nucleus accumbens shell. Brain Sci 2019, 9, 367. [CrossRef]

121. Zhao, B.; Wang, Y.; Li, Y.; Qiao, X.; Yan, P.; Zhu, Y.; Lai, J. Differential phosphorylation of NMDAR1-CaMKII-MAPKs in the rat nucleus accumbens following chronic ethanol exposure. Neurosci. Lett. 2015, 597, 60-65. [CrossRef] [PubMed]

122. Lee, K.M.; Coelho, M.A.; McGregor, H.A.; Solton, N.R.; Cohen, M.; Szumlinski, K.K. adolescent mice are resilient to alcohol withdrawal-induced anxiety and changes in indices of glutamate function within the nucleus accumbens. Front. Cell Neurosci 2016, 10, 265. [CrossRef] [PubMed]

123. Kash, T.L.; Baucum, A.J.; Conrad, K.L.; Colbran, R.J.; Winder, D.G. Alcohol exposure alters NMDAR function in the bed nucleus of the stria terminalis. Neuropsychopharmacology 2009, 34, 2420-2429. [CrossRef]

124. Zuo, W.; Wu, L.; Mei, Q.; Zuo, Q.; Zhou, Z.; Fu, R.; Li, W.; Wu, W.; Matthew, L.; Ye, J.H. Adaptation in 5-HT(2) receptors-CaMKII signaling in lateral habenula underlies increased nociceptive-sensitivity in ethanol-withdrawn rats. Neuropharmacology 2019, 158, 107747. [CrossRef] [PubMed]

125. Salling, M.C.; Faccidomo, S.P.; Li, C.; Psilos, K.; Galunas, C.; Spanos, M.; Agoglia, A.E.; Kash, T.L.; Hodge, C.W. Moderate alcohol drinking and the amygdala proteome: Identification and validation of calcium/calmodulin dependent kinase II and AMPA receptor activity as novel molecular mechanisms of the positive reinforcing effects of alcohol. Biol. Psychiatry 2016, 79, 430-442. [CrossRef] [PubMed]

126. Agoglia, A.E.; Holstein, S.E.; Reid, G.; Hodge, C.W. CaMKIIalpha-GluA1 activity underlies vulnerability to adolescent binge alcohol drinking. Alcohol Clin. Exp. Res. 2015, 39, 1680-1690. [CrossRef] 
127. Christian, D.T.; Alexander, N.J.; Diaz, M.R.; Robinson, S.; McCool, B.A. Chronic intermittent ethanol and withdrawal differentially modulate basolateral amygdala AMPA-type glutamate receptor function and trafficking. Neuropharmacology 2012, 62, 2430-2439. [CrossRef]

128. Wang, Y.; Cui, H.; Wang, W.; Zhao, B.; Lai, J. The region-specific activation of $\mathrm{Ca}^{2+} /$ calmodulin dependent $^{2}$ protein kinase II and extracellular signal-regulated kinases in hippocampus following chronic alcohol exposure. Brain Res. Bull. 2012, 89, 191-196. [CrossRef]

129. Mahadev, K.; Chetty, C.S.; Vemuri, M.C. Effect of prenatal and postnatal ethanol exposure on Ca ${ }^{2+}$ /calmodulin-dependent protein kinase II in rat cerebral cortex. Alcohol 2001, 23, 183-188. [CrossRef]

130. Fu, R.; Gregor, D.; Peng, Z.; Li, J.; Bekker, A.; Ye, J. Chronic intermittent voluntary alcohol drinking induces hyperalgesia in Sprague-Dawley rats. Int. J. Physiol. Pathophysiol. Pharmacol. 2015, 7, 136-144.

131. Li, J.; Li, Y.; Zhang, B.; Shen, X.; Zhao, H. Why depression and pain often coexist and mutually reinforce: Role of the lateral habenula. Exp. Neurol. 2016, 284, 106-113. [CrossRef]

132. Li, Y.; Wang, Y.; Xuan, C.; Li, Y.; Piao, L.; Li, J.; Zhao, H. Role of the lateral habenula in pain-associated depression. Front. Behav. Neurosci. 2017, 11,31. [CrossRef]

133. Sheng, J.; Liu, S.; Wang, Y.; Cui, R.; Zhang, X. The link between depression and chronic pain: Neural mechanisms in the brain. Neural Plast. 2017, 2017, 9724371. [CrossRef] [PubMed]

134. Delicata, F.; Bombardi, C.; Pierucci, M.; Di Maio, R.; De Deurwaerdère, P.; Di Giovanni, G. Preferential modulation of the lateral habenula activity by serotonin-2A rather than $-2 \mathrm{C}$ receptors: Electrophysiological and neuroanatomical evidence. CNS Neurosci. Ther. 2018, 24, 721-733. [CrossRef]

135. Guo, Y.; Zhang, L.; Zhang, J.; Du, C.-X.; Lv, S.-X.; Wang, T.; Wang, H.-S.; Xie, W.; Liu, J. Activation and blockade of serotonin 4 receptors in the lateral habenula improve working memory in unilateral 6-hydroxydopamine-lesioned Parkinson's rats. Neurol. Res. 2019, 41, 585-593. [PubMed]

136. Shabel, S.J.; Proulx, C.D.; Trias, A.; Murphy, R.T.; Malinow, R. Input to the lateral habenula from the basal ganglia is excitatory, aversive, and suppressed by serotonin. Neuron 2012, 74, 475-481. [CrossRef]

137. Xie, G.; Zuo, W.; Wu, L.; Li, W.; Wu, W.; Bekker, A.; Ye, J.-H. Serotonin modulates glutamatergic transmission to neurons in the lateral habenula. Sci. Rep. 2016, 6, 23798. [CrossRef] [PubMed]

138. Wang, J.; Carnicella, S.; Phamluong, K.; Jeanblanc, J.; Ronesi, J.A.; Chaudhri, N.; Janak, P.H.; Lovinger, D.M.; Ron, D. Ethanol induces long-term facilitation of NR2B-NMDA receptor activity in the dorsal striatum: Implications for alcohol drinking behavior. J. Neurosci. 2007, 27, 3593-3602. [CrossRef] [PubMed]

139. Hoffman, P.L.; Tabakoff, B. The role of the NMDA receptor in ethanol withdrawal. Exs 1994, 71, 61-70.

140. Mirshahi, T.; Woodward, J.J. Ethanol sensitivity of heteromeric NMDA receptors: Effects of subunit assembly, glycine and NMDAR1 Mg2+-insensitive mutants. Neuropharmacology 1995, 34, 347-355. [CrossRef]

141. Chu, B.; Anantharam, V.; Treistman, S.N. Ethanol inhibition of recombinant heteromeric NMDA channels in the presence and absence of modulators. J. Neurochem. 1995, 65, 140-148. [CrossRef] [PubMed]

142. Lovinger, D.M.; White, G.; Weight, F.F. Ethanol inhibits NMDA-activated ion current in hippocampal neurons. Science 1989, 243, 1721-1724. [CrossRef] [PubMed]

143. Lovinger, D.M.; White, G.; Weight, F.F. NMDA receptor-mediated synaptic excitation selectively inhibited by ethanol in hippocampal slice from adult rat. J. Neurosci. 1990, 10, 1372-1379. [CrossRef] [PubMed]

144. Kalluri, H.S.; Ticku, M.K. Effect of ethanol on phosphorylation of the NMDAR2B subunit in mouse cortical neurons. Mol. Brain Res. 1999, 68, 159-168. [CrossRef]

145. Kash, T.L.; Matthews, R.T.; Winder, D.G. Alcohol inhibits NR2B-containing NMDA receptors in the ventral bed nucleus of the stria terminalis. Neuropsychopharmacology 2008, 33, 1379-1390. [CrossRef]

146. Kalluri, H.S.; Mehta, A.K.; Ticku, M.K. Up-regulation of NMDA receptor subunits in rat brain following chronic ethanol treatment. Brain Res. Mol. Brain Res. 1998, 58, 221-224. [CrossRef]

147. Carpenter-Hyland, E.P.; Chandler, L.J. Homeostatic plasticity during alcohol exposure promotes enlargement of dendritic spines. Eur. J. Neurosci. 2006, 24, 3496-3506. [CrossRef]

148. Chandrasekar, R. Alcohol and NMDA receptor: Current research and future direction. Front. Mol. Neurosci. 2013, 6, 14. [CrossRef]

149. Hell, J.W. CaMKII: Claiming center stage in postsynaptic function and organization. Neuron 2014, 81, $249-265$. [CrossRef]

150. Fukunaga, K.; Stoppini, L.; Miyamoto, E.; Muller, D. Long-term potentiation is associated with an increased activity of $\mathrm{Ca}^{2+} /$ calmodulin-dependent protein kinase II. J. Biol. Chem. 1993, 268, 7863-7867. 
151. Kasahara, J.; Fukunaga, K.; Miyamoto, E. Activation of calcium/calmodulin-dependent protein kinase IV in long term potentiation in the rat hippocampal CA1 region. J. Biol. Chem. 2001, 276, 24044-24050. [CrossRef] [PubMed]

152. Fukunaga, K.; Muller, D.; Miyamoto, E. Increased phosphorylation of $\mathrm{Ca}^{2+} /$ calmodulin-dependent protein kinase II and its endogenous substrates in the induction of long-term potentiation. J. Biol. Chem. 1995, 270, 6119-6124. [CrossRef] [PubMed]

153. Fukunaga, K.; Muller, D.; Miyamoto, E. CaM kinase II in long-term potentiation. Neurochem. Int. 1996, 28, 343-358. [CrossRef]

154. Bredt, D.S.; Nicoll, R.A. AMPA receptor trafficking at excitatory synapses. Neuron 2003, 40, 361-379. [CrossRef]

155. Kryger, R.; Wilce, P. The effects of alcoholism on the human basolateral amygdala. Neuroscience 2010, 167, 361-371. [CrossRef] [PubMed]

156. Wang, J.; Hamida, S.B.; Darcq, E.; Zhu, W.; Gibb, S.L.; Lanfranco, M.F.; Carnicella, S.; Ron, D. Ethanol-mediated facilitation of AMPA receptor function in the dorsomedial striatum: Implications for alcohol drinking behavior. J. Neurosci. 2012, 32, 15124-15132. [CrossRef] [PubMed]

157. Meye, F.J.; Lecca, S.; Valentinova, K.; Mameli, M. Synaptic and cellular profile of neurons in the lateral habenula. Front. Hum. Neurosci. 2013, 7, 860. [CrossRef]

158. Rao, V.R.; Finkbeiner, S. NMDA and AMPA receptors: Old channels, new tricks. Trends Neurosci. 2007, 30, 284-291. [CrossRef]

159. Cannady, R.; Fisher, K.R.; Durant, B.; Besheer, J.; Hodge, C.W. Enhanced AMPA receptor activity increases operant alcohol self-administration and cue-induced reinstatement. Addict. Biol 2013, 18, 54-65. [CrossRef]

160. Mao, L.M.; Guo, M.L.; Jin, D.Z.; Fibuch, E.E.; Choe, E.S.; Wang, J.Q. Post-translational modification biology of glutamate receptors and drug addiction. Front. Neuroanat. 2011, 5, 19. [CrossRef]

161. Han, X.; Bian, E.; Li, J.; Zuo, W.; Mei, Q.; Fu, R.; Shiwalkar, N.; Fan, Q.; Gajewski, M.; Ye, J.-H. Pain, anxietyand depression-like behaviors in alcohol-preferring and -non-preferring rats. Neurol. Neurobiol. 2020, 3, 1-8.

162. Wang, J.; Li, M.; Wang, P.; Zha, Y.; He, Z.; Li, Z. Inhibition of the lateral habenular CaMKII abolishes naloxone-precipitated conditioned place aversion in morphine-dependent mice. Neurosci. Lett. 2017, 653, 64-70. [CrossRef]

163. Shah, A.; Zuo, W.; Kang, S.; Li, J.; Fu, R.; Zhang, H.; Bekker, A.; Ye, J.H. The lateral habenula and alcohol: Role of glutamate and M-type potassium channels. Pharm. Biochem. Behav. 2017, 162, 94-102. [CrossRef] [PubMed]

164. Berman, R.M.; Cappiello, A.; Anand, A.; Oren, D.A.; Heninger, G.R.; Charney, D.S.; Krystal, J.H. Antidepressant effects of ketamine in depressed patients. Biol. Psychiatry 2000, 47, 351-354. [CrossRef]

165. Regier, D.A.; Farmer, M.E.; Rae, D.S.; Locke, B.Z.; Keith, S.J.; Judd, L.L.; Goodwin, F.K. Comorbidity of mental disorders with alcohol and other drug abuse: Results from the epidemiologic catchment area (ECA) study. JAMA 1990, 264, 2511-2518. [CrossRef]

166. Kessler, R.C.; Nelson, C.B.; McGonagle, K.A.; Edlund, M.J.; Frank, R.G.; Leaf, P.J. The epidemiology of co-occurring addictive and mental disorders: Implications for prevention and service utilization. Am. J. Orthopsychiatry 1996, 66, 17-31. [CrossRef]

167. Grant, B.F.; Harford, T.C. Comorbidity between DSM-IV alcohol use disorders and major depression: Results of a national survey. Drug Alcohol Depend. 1995, 39, 197-206. [CrossRef]

168. Vaillant, G.E. Is alcoholism more often the cause or the result of depression? Harv Rev. Psychiatry 1993, 1, 94-99. [CrossRef]

169. Pettinati, H.M. Antidepressant treatment of co-occurring depression and alcohol dependence. Biol. Psychiatry 2004, 56, 785-792. [CrossRef]

170. Davis, L.; Uezato, A.; Newell, J.M.; Frazier, E. Major depression and comorbid substance use disorders. Curr. Opin. Psychiatry 2008, 21, 14-18. [CrossRef]

171. Hasin, D.S.; Stinson, F.S.; Ogburn, E.; Grant, B.F. Prevalence, correlates, disability, and comorbidity of DSM-IV alcohol abuse and dependence in the United States: Results from the National Epidemiologic Survey on Alcohol and Related Conditions. Arch. Gen. Psychiatry 2007, 64, 830-842. [CrossRef] [PubMed] 
172. Das, R.K.; Gale, G.; Walsh, K.; Hennessy, V.E.; Iskandar, G.; Mordecai, L.A.; Brandner, B.; Kindt, M.; Curran, H.V.; Kamboj, S.K. Ketamine can reduce harmful drinking by pharmacologically rewriting drinking memories. Nat. Commun. 2019, 10, 5187. [CrossRef]

173. Getachew, B.; Tizabi, Y. Both ketamine and NBQX attenuate alcohol-withdrawal induced depression in male rats. J. Drug Alcohol Res. 2019, 8, 236069. [CrossRef] [PubMed]

Publisher's Note: MDPI stays neutral with regard to jurisdictional claims in published maps and institutional affiliations.

(C) 2020 by the authors. Licensee MDPI, Basel, Switzerland. This article is an open access article distributed under the terms and conditions of the Creative Commons Attribution (CC BY) license (http://creativecommons.org/licenses/by/4.0/). 